\title{
Potential of the Centres of Traditional Folk Handicrafts of Podillia Region in Artistic-Labor Training of the Future Primary School Teacher
}

\author{
G. Buchkivska
}

\author{
Khmelnytskyi Humanitarian-Pedagogical Academy \\ Corresponding author. E-mail: buchkivska1810@gmail.com
}

Paper received 23.01.18; Revised 27.01.18; Accepted for publication 28.01.18.

https://doi.org/10.31174/SEND-PP2018-155VI65-02

\begin{abstract}
The article, based on the analysis of sources, reveals the importance of the centers of traditional folk handicrafts of Podillia region in artistic-labour training of the future primary school teacher. The peculiarities of the teacher's artistic-labor training to the use of works of folk handicrafts in the process of acquainting the children of junior school age with them have been analyzed, since the process of organizing the acquaintance of young people with the works of folk handicrafts requires highly thorough as well as scientifically and methodologically balanced approach.
\end{abstract}

Keywords: Podillia region, folk handicrafts, centres of traditional Podillia region handicrafts, artistic-labour training, future primary school teachers.

Introduction. The importance of folk crafts in our life was and remains important. It is thanks to folk crafts and trades that we can study the culture, traditions, life of our people, its history, national formation, etc. After all, "folk decorative art is the eternal life-giving source, fertile inspiration of deeply spiritual, artistic activity, creative genius of the Ukrainian people" [3, c. 29]. Due to this art, Ukraine is known in the world.

Ukrainian folk crafts have been developing for more than one millennium, and during this whole period they acquire the features of national identity, absorbing only the best that is in our nation. Familiarizing the descendants with the history, traditions and culture of their people, raising national consciousness and national selfesteem, as well as studying works of applied art of other peoples will help to form awareness of the importance of the Ukrainian people in the family of world communities.

The very process of organizing the familiarization of young people with the works of folk crafts requires highly diligent as well as scientifically and methodologically balanced approach.

Brief review of topical publications. The analysis of the scientific sources showed that the pedagogical science has a great deal of experience with regard to the problem of formation of creative personality in the process of artistic-labour activity. In particular, the works of Ye. Antonovych, V. Boichuk, N. Kardash, M. Kurach, H. Melnyk, M. Oleksiuk, L. Orshanskyi, H. Razumna, B. Prokopovych, L. Savka, I. Savchuk, T. Syrotenko, V. Tymenko, V. Tytarenko and others deal with the study of the problem of preparation of the future teachers in the field of decorative-applied arts, folk crafts and trades.

However, there is no definite unified approach to organizing the education and upbringing of primary pupils using works of folk decorative-applied art. Existing techniques reflect certain authors' positions, thoughts and experiences. Among the variety of names of scientists who contributed to the solution of the problem are T. Andrukhovych, E. Huliants, N. Kyrychenko, T. Naumenko, L. Sirchenko and others.

As for the researchers who studied the peculiarities of teaching children of the junior school age to the works of folk crafts in Podillia region, we are unlikely to be able to call some well-known surnames. The problem was studied only partly by the teachers of primary schools of Podillia region and it was not reflected in any solid scientific researches. We consider it necessary to detail the abovementioned problem and to determine the peculiarities of its solving during the professional training of the future teacher to the education and upbringing of children of primary school age.

The goal of this article is to analyze the peculiarities of the teacher's artistic-labor preparation to the use of works of folk crafts during the acquaintance with them of children of junior school age.

Materials and methods. The question of using the works of Podillia region folk crafts in the process of teaching and upbringing children of primary school age is quite peculiar. The features of the age development of children require working out the author's techniques, combining the study of works of folk crafts as well as general development and teaching in primary school. It is important to give equal attention to the study of all types of folk crafts, which Podillia region is rich in. The modern teacher should know what kinds of folk crafts exist, to know their history. It is also necessary to clearly understand the role of such art in the work with junior pupils, and in particular, its place in the upbringing of children of the corresponding age.

Podillia region folk crafts make up a significant part of Ukrainian decorative-applied art. The latter is called so because its works were or are the objects of everyday use, but from such objects these works are distinguished by their originality and bright artistic decoration.

In the dictionary we find the following definition: "Decorative-applied art is the branch of decorative art: creation of artistic products that have practical purpose in the public and private life and the artistic processing of utilitarian objects ... Decorative-applied art, which arose in antiquity, became one of the most important branches of folk art, its history is associated with artistic crafts, artistic industry, with the activity of professional painters and folk artists, at the beginning of the XXth century also with artistic design". [3, c. 152].

Decorative-applied art has a national factor on its basis. Its foundation is a craft, that is, "small manual production of finished products in the absence of internal production division of labor" [2, p. 18]. So today, we can talk about the following types of folk crafts or decorative-applied art that may be useful during the educational activity in primary school: chasing, engraving, ceramics and pottery, art glass, embroidery and wrapping on fabrics, lace, artistic 
tree and horn decorating, artistic painting. These types of decorative-applied art were developed widely in Podillia region.

With regard to the historically created types of decorative-applied art in Podillia region, it should be noted that their development was a centuries-long journey, and the art itself was gradually transformed from the applied, which has practical direction, to more decorative. This tendency was supported by the people who wanted to express their progressive preferences and ideas more clearly. The works of Podillia region folk crafts of the simplest subjects become more humanistic directed, they combine the achievements of the Renaissance, Baroque, Rococo and other artistic forms.

At the present stage of development of folk crafts Podillia region decorative-applied art is characterized by the brightness and richness of colors, the harmony or contrast of color combinations, the clarity and thoughtfulness of the form, the simplicity of the composition. The constituent part of the ornament of many types of Podillia region decorative art is vegetable motifs.

Works of Podillia decorative-applied art are available for perception at the junior school age and are the inexhaustible source of fostering the sense of beauty and the use of its motifs, compositions and colors in decorative drawing and appliqués. We will focus only on some types of folk crafts, which we need to use first when working with junior pupils. Undoubtedly, other kinds are also important, but we believe that it will be interesting for children not only to hear about the certain type of Podillia folk art, but also to try to recreate some objects, and the teacher's responsibility is to help the development of the children's desire to create objects with their own hands, to encourage them to work and sometimes to independent creative activity.

One of the common and affordable for children types of Podillia decorative art is embroidery. Folk craftsmen create beautiful ornaments in embroidery with the help of different techniques. Characteristic for the color combination in embroidery is tone transition from one color to another, but also there are works that are embroidered only in two traditional colors - red and black. Whatever the color scheme of the embroidery pattern is, they are always solemn, bright and cheerful. Embroidered shirts, coats, and towels become especially festive and decorative.

Pottery is a widely spread type of Podillia region decorative art. Podillia masters of ceramics produce various household items - crockery, decorative vases, jars, toys, etc., a significant part of these products are painted with vegetative ornament. The most accessible for children of junior school age are the ceramics of Chemerivtsi and Stara Ushytsia district masters. The products of the village of Letava are characterized by the following colors: brown (light and dark), beige, green, dark red. A simple composition is understood by schoolchildren. The significant part of the ceramic patterns can be completely or partially transferred to children's drawings, as the technique of execution, color combinations and simplicity of the composition is clear to children and is available for execution.

Podillia region decorative painting provides a wealth of material for drawing and applique classes. Various vege- tative motifs are masterfully reproduced in ornaments that decorate household items - furniture, crockery. In the decorative painting they use both the images of birds and animals. The villages of Samchyky in Khmelnytskyi region and Chernelivtsi in Vinnytsia region are considered to be the centers of Podillia decorative painting. Many masters of decorative painting create unique compositions on paper. Accordingly decorated, such works can perfectly embellish the interior of a modern institution of education. Bright, festive color combinations make these paintings particularly attractive. They have no details, specialities, there are only the most characteristic, important features of the subject, and at the same time they are sufficiently expressive.

Abundance and uniqueness of the products of decorative-applied art stipulate the wide application of them in the process of education and training of junior schoolchildren. The future teacher of primary school should be able to organize the activity of children, to enrich them with the necessary knowledge, using different methods and techniques. The children admire the beauty of objects made by hands of folk craftsmen. They understand that everything painted in a decorative pattern is taken from real life. The teacher should use for consideration such items of decorative art that are accessible to children and the ornament of which can be used for the full or partial reproduction in children's works. These are the objects of various types of contemporary Podillia region decorative art.

The value of toys is that in their external and functional characteristics, the following features (colour, form, texture of the material, etc.) are concentrated and deliberately highlighted, knowledge of which is essential for the schoolchildren. The following factors are of great importance: the material from which toys are made; size (of the toy itself or its parts); artistic-figurative solution (conditional or detailed); completeness of the toy (readymade, mountable-and-dismountable, etc.); peculiarities of functioning and so on.

Painted Easter egg is a miniature symbol of life; from ancient times it encrypted the world of the day, directing powerful cosmic force to a human and to everything that surrounds. By painted Easter egg ornaments - true masterpieces of decorative art - can be explained the greatness of the world, the awakening of nature, the relationship of the Earth with the heavenly bodies, the growth of plants and the movement of animals, the love to relatives and friends, to all people. In primary school it is advisable to familiarize children with a number of ornaments that are most common in modern Podillia region art of making painted Easter egg.

The success of making the artistic products by children depends on the amount of given knowledge about the customs, beliefs of Podillia region dwellers, the importance of making painted Easter egg as a type of decorative art, as well as the attitude of pupils themselves to the folk traditions of painting Easter eggs. Familiarizing children with certain types of decorative arts, in order to enrich their imagination, it is possible to show more complex subjects than those offered for making. When acquainting with the works of folk artists, the child feels respect of these people. There appears the desire to try to learn, to imitate. 
The children are attracted by the possibility of selfexpression. The latter has the output in making different goods of straw, wicker, clay, wood, etc. Even the observation as a preparatory work teaches children to analyze nature, to seek out invisible features, certain aesthetic qualities. This ability to see the world in different way is one of the components of aesthetic assessment of reality.

To carry out aesthetic education through the works of folk crafts of Podillia region is possible only if the teacher knows their pupils well, their interests and possibilities. By diversifying the forms of organization of children's activity and bringing knowledge, the teacher should find the new techniques, should be a friend and a partner to the children, and vary the forms of organization of classes. That is, the teacher should constantly and purposefully move to self-improvement.

Results and their discussion. To make decorativeapplied art become effective means of aesthetic education, it is necessary to adhere to a number of pedagogical conditions. It is, in particular, availability of children's perception of the selected material, presence of aesthetic environment in the group for the development of cognitivecreative activity of pupils; favourable microclimate of communication between pedagogues and children in and out of classes; accessibility and pedagogical expediency of the proposed tasks; variability of ways and forms of organization of children's activity; use of the latest educational technologies.

Thus, the course "Decorative-Applied Art" is one of the basic disciplines in the preparation of the future primary school teacher. The purpose of its study is: profound mastering of the students main historical and national trends of folk crafts as a prerequisite for the emergence of decorative-applied art and the creation of decorative goods made on the basis of understanding the concepts and categories of shaping, colour studies, composition and technical ways for the processing different materials. In addition to the standardized study of decorative-applied art, the future primary school teachers have the opportunity to choose special courses of this direction and to have practical work in educational workshops. The programs on the courses "Folk Crafts and Trades", "Fundamentals of Artistic Work" include acquaintance with the history of the decorative-applied art of Ukraine, obtaining theoretical and practical principles of the general methodology of teaching the subject, assimilation of a number of technical methods of decorative character, development of artistic thought, creative imagination of the future teachers. The student should learn how to make decorative-applied goods on the basis of their design and construction, analysis of structural materials. The analysis of the experience of preparing primary school teachers indicates the need for its content renewal, strengthening the technological and methodological direction. In particular, the study of the provisions of art-pedagogy, artistic pedagogy, psychology of children's creativity, theory and practice of work in the institutions of extracurricular education, fundamentals of designing and constructing goods are relevant.

The developing potential of folk decorative-applied art considerably grows due to the practical mastering of its laws and regularities, artistic mastery and creative character of this activity. The authentic works of artistic culture of people are the valuable model for the future teacher, both in terms of the emergence of figurative idea, and its subject embodiment. At every stage of creation, the decorative-applied art has the possibilities of cognition of the intellectual side of spiritual-material life and the manifestation of the emotional activity when realizing the creative potential. It should be mentioned that in the decorativeapplied art these forms of psychological activity are mutually stipulated - emotional cognition becomes intellectual, and intellectual - emotional. Consequently decorative-applied art functions as an integral system, which figuratively models the external world and the human, using specific abilities of the language of decorating and ornament. Besides, in the process of making a decorativeapplied good, one needs training of the organs of perception: vision, tactile sensitivity, feeling of the colour, composition, etc. The subject of decorative-applied art demands "special eye", which can see in the new way sharper and more precise - the objects of the external world, stylize them into the elements and motifs of the ornament" [9, c. 27].

Artistic perception has its features, it differs by the nature of the course and gets special form. The artist's, folk master's thinking differs by the ability to use images, conceptions, integral, stylized structures. The abilities of the decorative-applied art in the formation of the thinking activity of a personality, which has the feelings, emotions, experiences and which is determined as "figurative thinking", are unlimited. Formation and development of figurative thinking depends on the abundance and delicacy of visual images, acquisition of which stipulates perception of the works of decorative-applied art. In decorating a person should have continuous practice, due to which special abilities and skills are formed. The process of decorating has the downright attitude to the creation of artistic image in material.

However, it should be mentioned that on the one hand artistic-labour activity is a process of "gathering" personal spiritual world, transforming different qualities and properties, various human impulses and energy into the image of understanding, active, socially-responsible personality. That is why it is a powerful resource in forming creative activity of a student. And on the other hand it is a form of manifestation of creative activity, which level of formedness determines its qualitative characteristics.

In practical activity, the future primary school teachers should demonstrate maximum mutual understanding of the interests of schoolchildren, provide them with a wide field for the manifestation of imagination, embodiment of various ideas, albeit sometimes absurd. If we insist on fulfilling a certain task with all children alike, without taking into account their position, we will never achieve effective result. If our children, after listening, seeing, touching certain works of decorative-applied art, want to make their own compositions, it must surely be greeted, because their creativity is manifested in this form. One must see among the confusion of children's forms and results that spirituality, that image, which the children see themselves.

Conclusions. Therefore, the main goal of the pedagogical process should be the development by means of art not only of the aesthetic tastes, but also for the natural positive tendencies of children, their interests, abilities, 
talents, and creative thinking. The reorientation of the educational process to the child's personality stipulates the observance of certain principles in the organization of aesthetic education, in particular, its implementation on the national basis.

The teacher's knowledge of the types of folk crafts is rather important. Among the main features of preparation of the teacher to familiarize children of junior school age with the works of Podillia region folk artists, we can call the following: implementation of personally oriented ap- proach, selection of individual tasks, developing interest and forming positive motivation to study, learning the best experience of practicing teachers and scientific regulations as for the organization of training and upbringing by means of folk crafts in primary school, use of interdisciplinary connections and planning of training in small groups during preparation for classes and organization of integrated lessons as a means of stimulating creative activity of primary school pupils.

\section{ЛІТЕРАТУРА}

1. Антонович Є.А. Декоративно-прикладне мистецтво навч. посіб. / Є.А. Антонович, Р.В. Захарчук-Чугай, М.С. Станкевич. - Львів : Світ, 1993. - 272 с. : іл., табл.

2. Захарчук-Чугай Р.В. Українське народне декоративне мистецтво : навч. посіб. / Р.В. Захарчук-Чугай, Є.А. Антонович. - Київ : Знання, 2012. - 342 с., XXXII с.кольор. іл.

3. Декоративно-ужиткове мистецтво : словник : в 2 т. Т. 1 : А-К / за заг. ред. Я. П. Запаска. - Львів : Афіша, 2000. 363 с. : іл. 23.

4. Оршанський Л. В. Художньо-трудова підготовка майбутніх учителів трудового навчання : монографія / Л. В. Оршанський. - Дрогобич : Швидко Друк, 2008. $278 \mathrm{c}$.

5. Селівачов М.Р. Народне декоративне мистецтво. Художні промисли / М.Р. Селівачов // Історія української культури : У 5 т. / НАН України. - К.: Наукова думка, 2005. - Т.4:

Українська культура другої половини ХІХ ст., Кн.2. - С. $1153-1232$

6. Стан Т.С. Майстри декоративно-прикладного мистецтва Хмельниччини. Фотоальбом / Т.С.Стан . - Хмельницький, 2006. -60 с.: іл.

7. Тищенко О.Р. Декоративно-прикладне мистецтво східних слов'ян і давньоруської народності. - К., 1985. - 276 с.

8. Урсу Н.О. Нариси з історії образотворчого і декоративноприкладного мистецтва Хмельниччини : навчальний посібник для студентів художніх спеціальностей / Н.О.Урсу. - Кам'янець-Подільський : Аксіома, 2012. 224 с.: іл.

9. Щербаківський В. Українське мистецтво: Вибрані неопубліковані праці / В. Щербаківський; упоряд., вст. ст. В.Ульяновського; додатки П. Герчанівської, В. Ульяновського. - К.: Либідь, 1995. - 228 с.: іл.

\section{REFERENCES}

1. Antonovych Ye.A. Dekoratyvno-prykladne mystetstvo [Decorative-Applied Art]: navch. posib. / Ye. A. Antonovych, R.V. Zakharchuk-Chuhai, M. Ye. Stankevych. - Lviv : Svit, 1993. - 272 s. : il., tabl. [in Ukrainian].

2. Zakharchuk-Chuhai R.V. Ukrainske narodne dekoratyvne mystetstvo. [Ukrainian Decorative-Applied Art]: navch. posib. / R.V. Zakharchuk-Chuhai, Ye. A. Antonovych. - Kyiv: Znannia, 2012. - 342 s., XXXII s.kolior. il. [in Ukrainian].

3. Dekoratyvno-uzhytkove mystetstvo: slovnyk [DecorativeApplied Art: Dictionary] : v 2 t. T. 1 : A-K / za zah. red. Ya. P. Zapaska. - Lviv : Afisha, 2000. - 363 s. : il. 23. [in Ukrainian].

4. Orshanskyi L. V. (2008) Khudozhno-trudova pidhotovka maibutnikh uchyteliv trudovoho navchannia [Artistic-Labor Training of the Future Teachers of Labor Education]. Drohobych: Quick print, 278 p. [in Ukrainian].

5. Selivachov, M.R. Narodne dekoratyvne mystetstvo. Khudozhni promysly [Folk Decorative Arts. Artistic Craftworks] / M.R. Selivachov // Istoriia ukrainskoi kultury :

U 5 t. / NAN Ukrainy. - K.: Naukova dumka, 2005. - T.4: Ukrainska kultura druhoi polovyny XIX st., Kn.2. - S. 1153 1232. [in Ukrainian].

6. Tyshchenko O.R. Dekoratyvno-prykladne mystetstvo skhidnykh slovian i davnioruskoi narodnosti [Decorative-Applied Art of Eastern Slavs and Ancient Rus People] - K., 1985. 276 s. [in Ukrainian].

7. Stan T.S. Maistry dekoratyvno-prykladnoho mystetstva Khmelnychchyny. Fotoalbom [Masters of DecorativeApplied Art of Khmelnytskyi Region] / T.S.Stan .- Khmelnytskyi, 2006. -60 s.: il. [in Ukrainian].

8. Ursu N.O. Narysy z istorii obrazotvorchoho i dekoratyvnoprykladnoho mystetstva Khmelnychchyny [Sketches from the History of Descriptive and Decorative-Applied Art of Khmelnytskyi Region]: navchalnyi posibnyk dlia studentiv khudozhnikh spetsialnostei / N.O.Ursu. - KamianetsPodilskyi : Aksioma, 2012. - 224 s.: il. [in Ukrainian].

9. Shcherbakivskyi V. (1995) Ukrainske mystetstvo: Vybrani neopublikovani pratsi [Ukrainian Art: Selected Unpublished Works]. Kiev: Lybid, 228 p. [in Ukrainian].

Потенциал центров традиционных народных ремесел Подолья в художественно-трудовой подготовке будущего учителя начальных классов

\section{Г. Бучковская}

Аннотация. В статье на основе анализа источников, раскрывается значение центров традиционных народных ремесел подольского региона в художественно-трудавий подготовке будущего учителя начальных классов. Проанализированы особенности художественно-трудовой подготовки учителя к использованию произведений народных ремесел во время ознакомления с ними детей младшего школьного возраста, ведь процесс организации ознакомления молодежи с произведениями народных ремесел требует очень тщательного и научно и методически взвешенного подхода.

Ключевые слова: Подолье, народные ремесла, иеентры традиционных подольских ремесел, художественно-трудовая подготовка, будущчие учителя начальных классов. 